\title{
Performance Based Evaluation of Industrial Grade Resins Duolite ARA-9366 and Duolite A-368
}

DOI: $10.15255 /$ KUI.2013.010

KUI-14/2014

Received April 27, 2013

Accepted August 26, 2013

\author{
P. U. Singare \\ Department of Chemistry, Bhavan's College, Munshi Nagar, Andheri (West), 400058 Mumbai, India
}

\begin{abstract}
This study deals with performance evaluation of nuclear and non-nuclear grade resins Duolite ARA-9366 and Duolite A-368 by application of the radioanalytical technique. The evaluation was made based on kinetics data of ion-isotopic exchange reactions using ${ }^{131} \mathrm{I}$ and ${ }^{82} \mathrm{Br}$ radioactive tracer isotopes. It was observed that under identical experimental conditions of $35.0{ }^{\circ} \mathrm{C}, 1.000 \mathrm{~g}$ of ion exchange resins and $0.002 \mathrm{~mol} \mathrm{I}^{-1}$ labelled iodide ion solution, the values of specific reaction rate in $\min ^{-1}$ and initial rate of iodide ion exchange in $\mathrm{mmol} \mathrm{min}^{-1}$ was 0.173 and 0.044 respectively for Duolite ARA-9366 resin; that was higher than the values of 0.129 and 0.030 respectively reported for Duolite A-368 resins. The identical trend was observed for the two resins during bromide ion-isotopic exchange reaction. The results of this investigation show the existence of a strong positive co-relationship between the amount of ions exchanged and the concentration of ionic solution; as well as the existence of a strong negative co-relationship between the amount of ions exchanged and the temperature of the exchanging medium for both resins. The overall results indicate superior performance of Duolite ARA-9366 over Duolite A-368 under identical experimental conditions.
\end{abstract}

Key words: Ion exchange resins, radiotracer isotopes, reaction kinetics, Duolite ARA-9366, Duolite A-368, ${ }^{131} I,{ }^{82} \mathrm{Br}$

\section{Introduction}

Ion exchange resins are used in several chemical decontamination or cleaning processes and in nuclear industries for removal of radionuclides. ${ }^{1-5}$ Nowadays, ion exchange resins are not only used for separation but also as catalysts. In the past decade, inorganic ion exchange materials have emerged as an increasingly important replacement or complement to conventional organic ion exchange resins. Nevertheless, in many cases, for specific physical and chemical reasons, organic resins cannot be replaced by inorganic ion exchangers, and thus organic ion exchange resins continue to be applied globally in various industries. ${ }^{1-5}$ Therefore, the development of new organic ion exchange materials for specific industrial and technological applications is a great challenge to present-day researchers. In order to bring about the efficient and economic application of ion exchange resins in various industrial processes, efforts are being continuously made to develop new ion exchangers. ${ }^{6-8}$ Development of ion exchange resins is usually followed by characterization to understand the performance of those resins in various technological applications. ${ }^{9-12}$ Although several techniques are available for the characterization of ion exchange resins, ${ }^{13-17}$ the radiotracer technique offers several advantages such as high detection sensitivity, capability of in-situ detection, limited memory effects and physico-chemical compatibility with the material under study. ${ }^{18}$

Hence, in the present investigation, ${ }^{131} \mathrm{I}$ and ${ }^{82} \mathrm{Br}$ radiotracer isotopes were applied to assess the performance of

\footnotetext{
* Dr. Pravin Uttam Singare

e-mail: pravinsingare@gmail.com
}

Duolite ARA-9366, a nuclear grade, and Duolite A-368, a non-nuclear grade anion exchange resin under different experimental conditions as temperature and concentration of ionic species present in the external exchanging medium.

\section{Experimental}

\section{Materials}

Ion exchange resin Duolite ARA-9366 was a nuclear grade strong base anion exchange resin in hydroxide form having quaternary ammonium functional group and crosslinked polystyrene divinyl benzene matrix. The moisture content of the resin was $55 \%$, total exchange capacity was $1.04 \mathrm{mmol} \mathrm{ml}^{-1}$, and the resin was designed to operate in the $\mathrm{pH}$ range of $0-14$. Duolite A-368 was a weak base anion exchange resin also in hydroxide form, having tertiary ammonium functional groups and crosslinked polystyrene matrix. The moisture content of the resin was $46 \%$, the total exchange capacity was $1.70 \mathrm{mmol} \mathrm{ml}^{-1}$, and the resin was capable of operating in the $\mathrm{pH}$ range of $0-7$. The particle size of the two resins was in the range of $0.3-1.2 \mathrm{~mm}$ and maximum operating temperature was $60.0^{\circ} \mathrm{C}$. Both resins were supplied by Auchtel Products Ltd., Mumbai, India.

The radioactive isotope ${ }^{131}$ I was an aqueous solution of sodium iodide in dilute sodium sulphite having a half-life of $8.04 \mathrm{~d}$, radioactivity of $5 \mathrm{mCi}$ and $\mathrm{\gamma}$-ray energy of $0.36 \mathrm{MeV}$. Radioactive isotope ${ }^{82} \mathrm{Br}$ used in the present experimental work was an aqueous solution of ammonium bromide in dilute ammonium hydroxide having a half-life of $36 \mathrm{~h}$, radioactivity of $5 \mathrm{mCi}$ and $\gamma$-ray energy of $0.55 \mathrm{MeV} .{ }^{19}$ Both radioactive isotopes were obtained from Board of Radiation and Isotope Technology (BRIT), Mumbai, India. 


\section{Conditioning of ion exchange resins}

These resins were converted separately into iodide/bromide form by treatment with $10 \% \mathrm{Kl} / \mathrm{KBr}$ solution in a conditioning column at the flow rate of $1 \mathrm{ml} \mathrm{min}{ }^{-1}$. The conditioned resins were then washed with double distilled water, until the washings were free from iodide/bromide ions as tested by $\mathrm{AgNO}_{3}$ solution. These resins in bromide and iodide form were then dried separately over $\mathrm{P}_{2} \mathrm{O}_{5}$ in desiccators at room temperature.

\section{lodide ion-isotopic exchange reaction kinetics}

The ${ }^{131}$ radioactive isotope was used to label $250 \mathrm{ml}$ iodide ion solution of $0.001 \mathrm{~mol} \mathrm{I}^{-1}$ concentration taken in a stoppered bottle. The labelling of solution was done using a micro syringe in such a way that $1.0 \mathrm{ml}$ of labelled solution shall have radioactivity of around $15000 \mathrm{cpm}$ (counts per minute) when measured with $\gamma$-ray spectrometer having $\mathrm{Nal}(\mathrm{Tl})$ scintillation detector. The concentration of labelled iodide ion solution was assumed to remain unchanged since only about $50-100 \mu \mathrm{l}$ of the radioactive iodide ion solution was used for labelling the solution that was further confirmed by potentiometric titration against $\mathrm{AgNO}_{3}$. The labelled iodide ion solution of known initial radioactivity $\left(A_{i}\right)$ was placed in a thermostat that was pre-adjusted to $30.0^{\circ} \mathrm{C}$. To the labelled iodide ion solution the swelled and conditioned dry ion exchange resins in iodide form weighing exactly $1.000 \mathrm{~g}$ were transferred quickly and the solution was vigorously stirred with mechanical stirrer. The radioactivity in cpm of $1.0 \mathrm{ml}$ of solution was measured at a regular 2-minute intervals and the solution was transferred back to the same bottle containing labelled solution after measur- ing radioactivity. The iodide ion-isotopic exchange reaction may be represented as:

$$
\mathrm{R}-\mathrm{I}+{ }^{131} \mathrm{I}^{-}(\mathrm{aq}) \rightleftharpoons \mathrm{R}-{ }^{131} \mathrm{I}+\mathrm{I}^{-}(\mathrm{aq})
$$

where $\mathrm{R}-\mathrm{I}$ represents ion exchange resin in iodide form; ${ }^{131} \mathrm{I}^{-}$(aq) represents aqueous iodide ion solution labelled with ${ }^{131}$ I radiotracer isotope.

Based on previous experiments, ${ }^{20-25}$ it was observed that within a time span of $3 \mathrm{~h}$ the above exchange reaction attains equilibrium, so the radioactivity measured after $3 \mathrm{~h}$ gives the final radioactivity $\left(A_{f}\right)$ of the solution. The radioactivity measured at various time intervals was corrected for background counts.

The experiments were repeated in a similar manner by equilibrating separately $1.000 \mathrm{~g}$ of ion exchange resin in iodide form with labelled iodide ion solution of four different concentrations ranging up to $0.004 \mathrm{~mol} \mathrm{I}^{-1}$ at a constant temperature of $30.0^{\circ} \mathrm{C}$. The above experiment was extended further for higher temperatures up to $45.0^{\circ} \mathrm{C}$.

\section{Bromide ion-isotopic exchange reaction kinetics}

The experiment was also done to study the kinetics of bromide ion-isotopic exchange reaction by equilibrating $1.000 \mathrm{~g}$ of ion exchange resin in bromide form with labelled bromide ion solution in the same concentration and temperature range as above. For labelling the bromide ion solution ${ }^{82} \mathrm{Br}$ radioactive tracer isotope was used and the labelling of solution was done by the same procedure as explained

Ta b l e 1 - Effect of ion concentration on iodide and bromide ion-isotopic exchange reactions. Mass of ion exchange resin $=1.000 \mathrm{~g}$, volume of labelled ionic solution $=250 \mathrm{ml}$, temperature $=35.0^{\circ} \mathrm{C}$.

Ta b I i c a 1 - Utjecaj koncentracije iona na reakcije izmjene jodidnog i bromidnog iona. Masa ionskoizmjenjivačke smole $=1,000$, obujam obilježene ionske otopine $=250 \mathrm{ml}$, temperatura $=35,0^{\circ} \mathrm{C}$.

\begin{tabular}{|c|c|c|c|c|c|c|c|c|c|c|c|c|c|c|c|c|c|}
\hline \multirow[b]{3}{*}{ 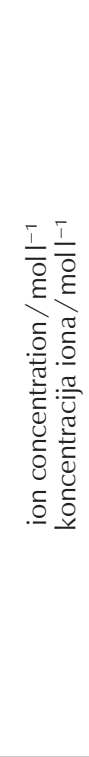 } & \multirow[b]{3}{*}{ 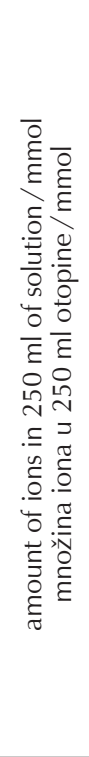 } & \multicolumn{8}{|c|}{$\begin{array}{l}\text { Iodide exchange } \\
\text { Izmjena jodida }\end{array}$} & \multicolumn{8}{|c|}{$\begin{array}{l}\text { Bromide exchange } \\
\text { Izmjena bromida }\end{array}$} \\
\hline & & \multicolumn{4}{|c|}{ Duolite ARA-9366 } & \multicolumn{4}{|c|}{ Duolite A-368 } & \multicolumn{4}{|c|}{ Duolite ARA-9366 } & \multicolumn{4}{|c|}{ Duolite A-368 } \\
\hline & & 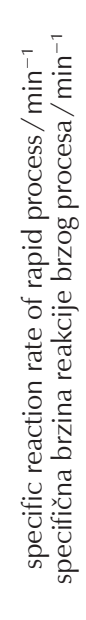 & 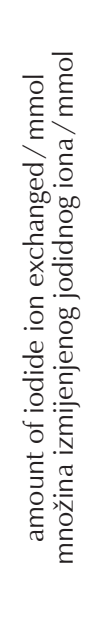 & 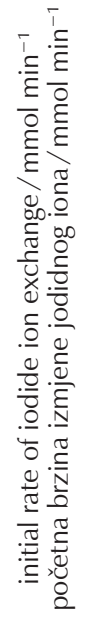 & 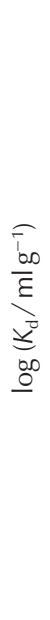 & 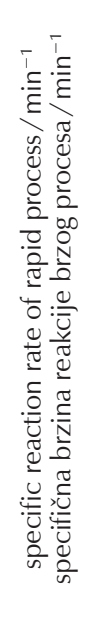 & 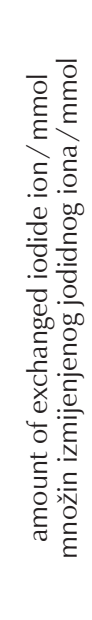 & 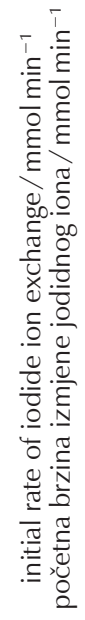 & 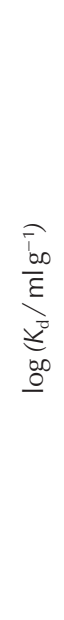 & 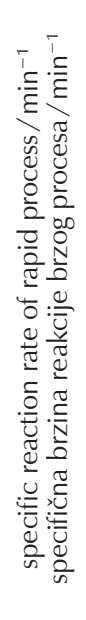 & 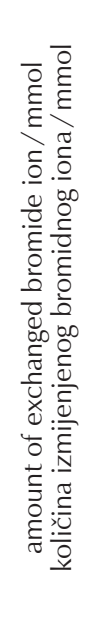 & 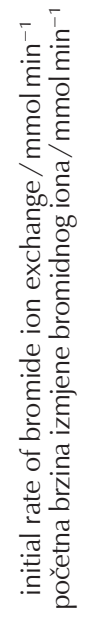 & 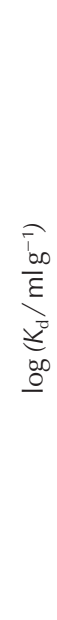 & 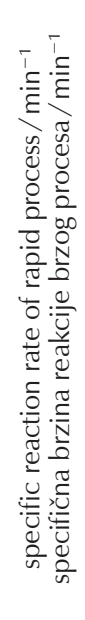 & 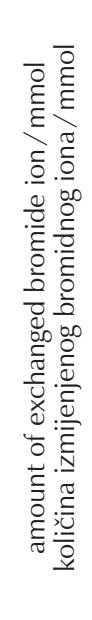 & 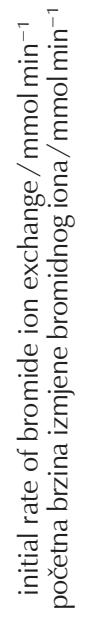 & $\frac{\widehat{b}}{\bar{\varepsilon}}$ \\
\hline 0.001 & 0.250 & 0.164 & 0.125 & 0.021 & 7.4 & 0.112 & 0.113 & 0.013 & 6.4 & 0.135 & 0.106 & 0.014 & 3.6 & 0.097 & 0.094 & 0.009 & 2.7 \\
\hline 0.002 & 0.500 & 0.173 & 0.256 & 0.044 & 7.9 & 0.129 & 0.231 & 0.030 & 6.9 & 0.142 & 0.221 & 0.031 & 4.5 & 0.105 & 0.196 & 0.021 & 3.5 \\
\hline 0.003 & 0.750 & 0.185 & 0.389 & 0.072 & 8.5 & 0.141 & 0.352 & 0.050 & 7.6 & 0.147 & 0.344 & 0.050 & 5.0 & 0.118 & 0.306 & 0.036 & 4.0 \\
\hline 0.004 & 1.000 & 0.200 & 0.525 & 0.105 & 8.9 & 0.153 & 0.475 & 0.073 & 8.0 & 0.151 & 0.471 & 0.071 & 5.6 & 0.126 & 0.421 & 0.053 & 4.5 \\
\hline
\end{tabular}


Ta ble 2 - Effect of temperature on iodide and bromide ion-isotopic exchange reactions. Mass of ion exchange resin $=1.000 \mathrm{~g}$, concentration of labelled exchangeable ionic solution $=0.002 \mathrm{moll}^{-1}$, volume of labelled ionic solution $=250 \mathrm{ml}$, amount of exchangeable ions in $250 \mathrm{ml}$ of labelled solution $=0.500 \mathrm{mmol}$.

Ta b I i c a 2 - Utjecaj temperature na reakcije izmjene jodidnog i bromidnog iona. Masa ionskoizmjenjivačke smole = 1,000 g, koncentracija obilježene otopine izmjenjivih iona $=0,002 \mathrm{moll}^{-1}$, obujam obilježene ionske otopine $=250 \mathrm{ml}$, množina izmjenjivih iona u $250 \mathrm{ml}$ obilježene otopine $=0,500 \mathrm{mmol}$.

\begin{tabular}{|c|c|c|c|c|c|c|c|c|c|c|c|c|c|c|c|c|}
\hline \multirow[b]{3}{*}{ 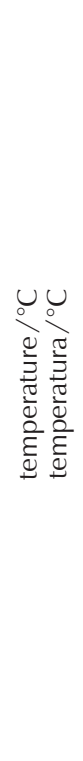 } & \multicolumn{8}{|c|}{$\begin{array}{l}\text { Iodide exchange } \\
\text { Izmjena jodida }\end{array}$} & \multicolumn{8}{|c|}{$\begin{array}{l}\text { Bromide exchange } \\
\text { Izmjena bromida }\end{array}$} \\
\hline & \multicolumn{4}{|c|}{ Duolite ARA-9366 } & \multicolumn{4}{|c|}{ Duolite A-368 } & \multicolumn{4}{|c|}{ Duolite ARA-9366 } & \multicolumn{4}{|c|}{ Duolite A-368 } \\
\hline & 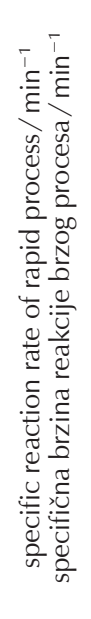 & 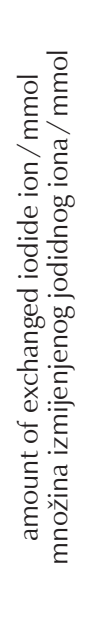 & 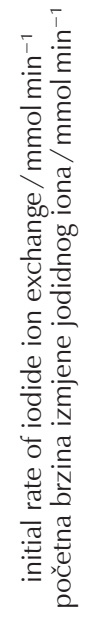 & 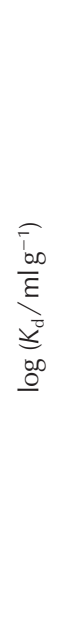 & 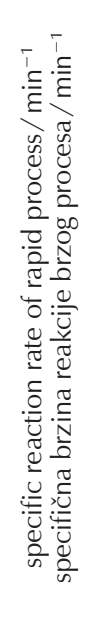 & 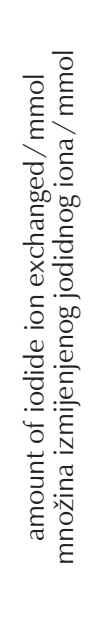 & 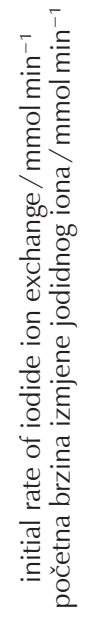 & 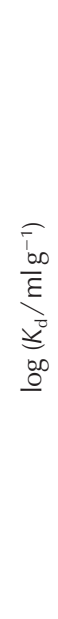 & 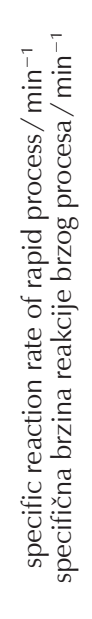 & 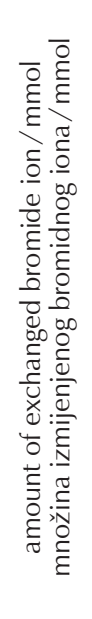 & 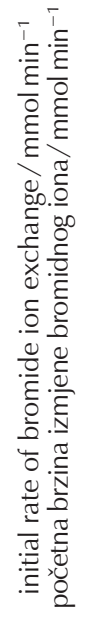 & 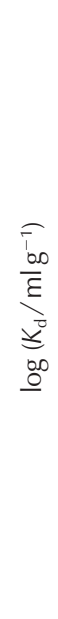 & 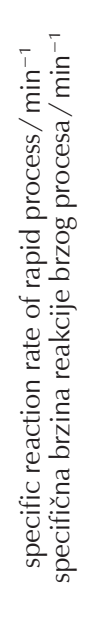 & 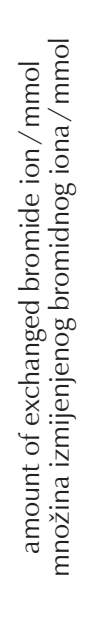 & 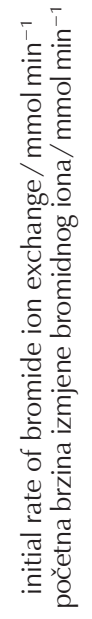 & 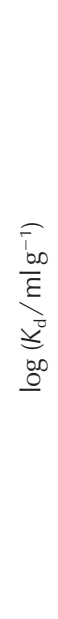 \\
\hline 30.0 & 0.185 & 0.260 & 0.048 & 8.4 & 0.140 & 0.235 & 0.033 & 1.0 & 0.147 & 0.232 & 0.034 & 3.2 & S1. & 0.207 & 0.023 & 4.4 \\
\hline 35.0 & 0.173 & 0.256 & 0.044 & 7.9 & 0.129 & 0.231 & 0.030 & 6.9 & 0.142 & 0.221 & 0.031 & 4.5 & 0.105 & 0.196 & 0.021 & 3.5 \\
\hline 40.0 & 0.164 & 0.251 & 0.041 & 7.2 & 0.118 & 0.226 & 0.027 & 6.2 & 0.136 & 0.213 & 0.029 & 4.0 & 0.100 & 0.188 & 0.019 & 3.2 \\
\hline 45.0 & 0.155 & 0.248 & 0.038 & 6.8 & 0.109 & 0.223 & 0.024 & 5.8 & 0.127 & 0.202 & 0.026 & 3.5 & 0.091 & 0.177 & 0.016 & 2.8 \\
\hline
\end{tabular}

above. The bromide ion-isotopic exchange reaction may be represented as:

$$
\mathrm{R}-\mathrm{Br}+{ }^{82} \mathrm{Br}^{-}(\mathrm{aq}) \rightleftharpoons \mathrm{R}-{ }^{82} \mathrm{Br}+\mathrm{Br}^{-}(\mathrm{aq})
$$

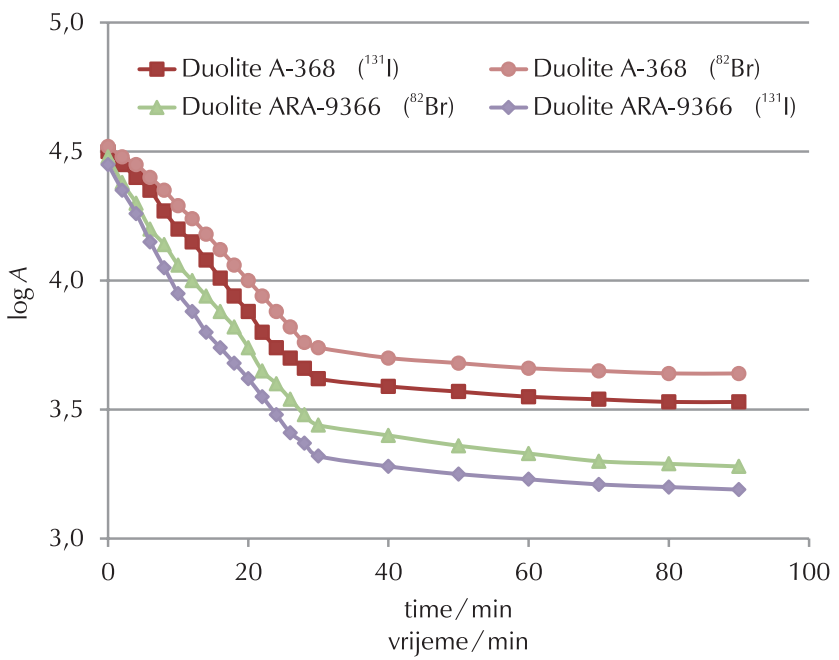

F i g . 1 - Kinetics of iodide and bromide ion-isotopic exchange. Mass of ion exchange resin $=1.000 \mathrm{~g}$, concentration of labelled exchangeable ionic solution $=0.002 \mathrm{~mol}^{-1}$, volume of labelled ionic solution $=250 \mathrm{ml}$, temperature $=35.0^{\circ} \mathrm{C}$.

S I i k a 1 - Kinetika ionsko-izotopne izmjene jodida i bromida. Masa ionskoizmjenjivačke smole $=1,000 \mathrm{~g}$, koncentracija obilježene otopine izmjenjivih iona $=0,002 \mathrm{~mol}^{-1}$, obujam obilježene ionske otopine $=250 \mathrm{ml}$, temperatura $=35,0^{\circ} \mathrm{C}$ where $\mathrm{R}-\mathrm{Br}$ represents ion exchange resin in bromide form; ${ }^{82} \mathrm{Br}^{-}$(aq) represents aqueous bromide ion solution labelled with ${ }^{82} \mathrm{Br}$ radiotracer isotope.

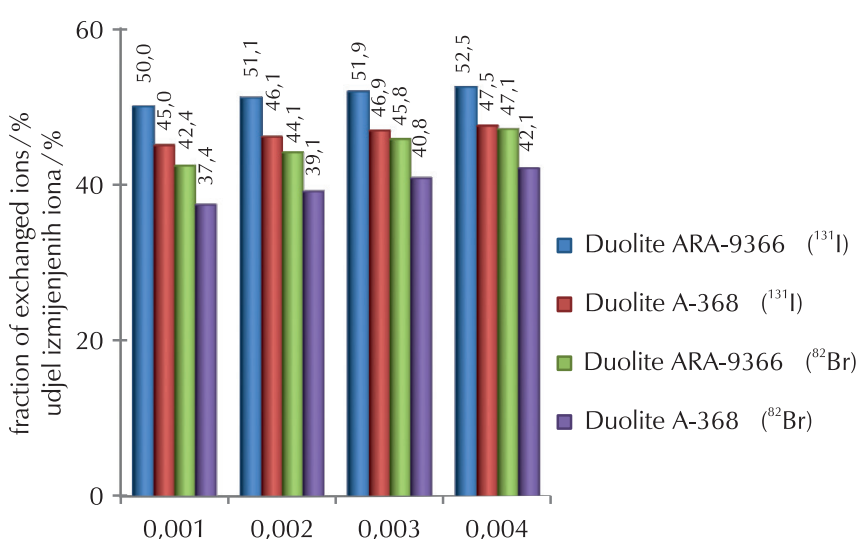

$\begin{array}{llll}0,001 & 0,002 & 0,003 & 0,004\end{array}$

concentration of labeled ion solution $/ \mathrm{mol} \mathrm{I}^{-1}$

koncentracija iona u obilježenoj otopini / $\mathrm{mol} \mathrm{I}^{-1}$

Fig. 2 - Effect of ionic concentration on fraction of ions exchanged during iodide and bromide ion-isotopic exchange reactions. Mass of ion exchange resin $=1.000 \mathrm{~g}$, volume of labelled ionic solution $=250 \mathrm{ml}$, temperature $=35.0^{\circ} \mathrm{C}$.

SIika 2 - Utjecaj ionske koncentracije na postotak izmijenjenih jodidnih i bromidnih iona tijekom ionsko-izotopne reakcije izmjene, masa ionskoizmjenjivačke smole $=1,000 \mathrm{~g}$, obujam obilježene ionske otopine $=250 \mathrm{ml}$, temperatura $=35,0^{\circ} \mathrm{C}$. 


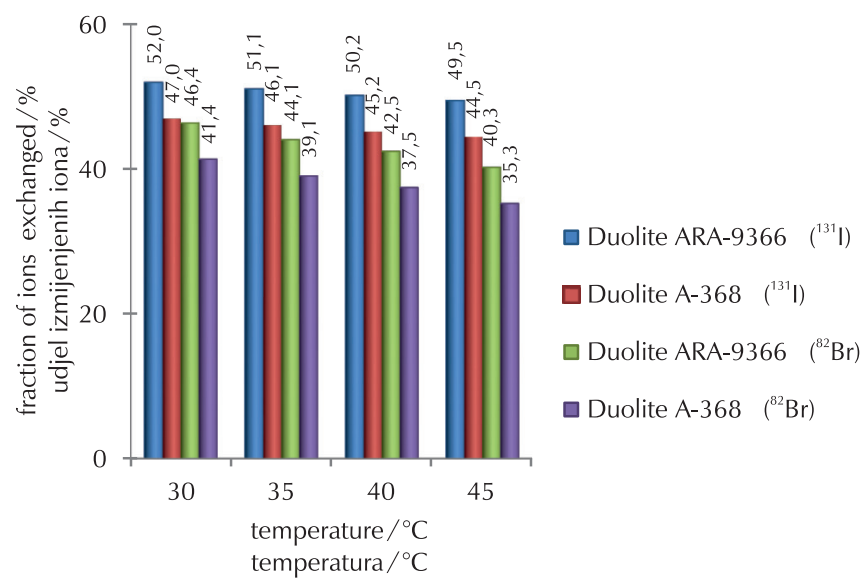

Fig. 3 - Effect of temperature on fraction of ions exchanged during iodide and bromide ion-isotopic exchange reactions. Mass of ion exchange resin $=1.000 \mathrm{~g}$, concentration of labelled exchangeable ion solution $=0.002 \mathrm{moll}^{-1}$, volume of labelled ionic solution $=250 \mathrm{ml}$, amount of exchangeable ions in $250 \mathrm{ml}$ of labelled solution $=0.500 \mathrm{mmol}$.

SI i k a 3 - Utjecaj temperature na udjel izmijenjenih jodidnih $i$ bromidnih iona tijekom ionsko-izotopne reakcije izmjene. Masa ionskoizmjenjivačke smole $=1,000 \mathrm{~g}$, koncentracija obilježene otopine izmjenjivih iona $=0,002 \mathrm{moll}^{-1}$, obujam obilježene ionske otopine $=250 \mathrm{ml}$, množina izmjenjivih iona u $250 \mathrm{ml}$ obilježene otopine $=0,500 \mathrm{mmol}$.

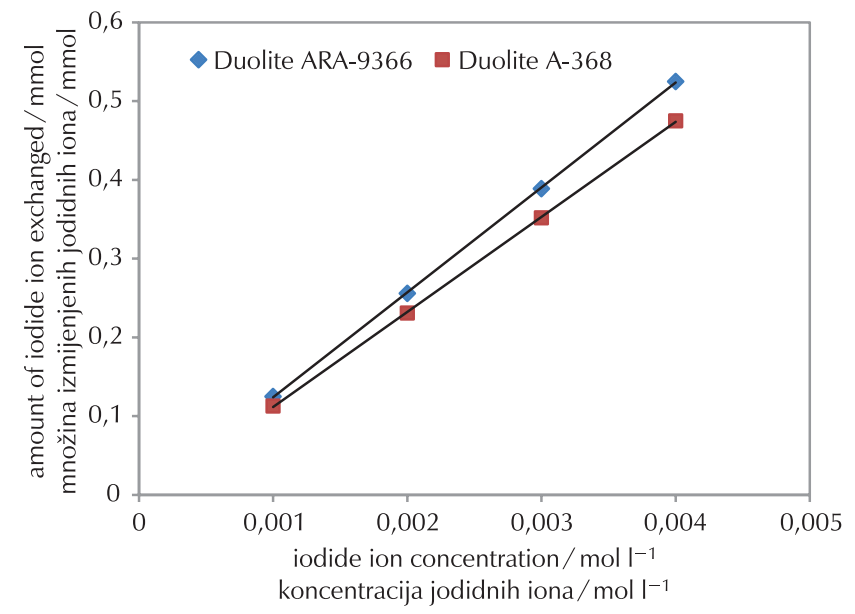

F i g . 4 - Statistical correlation between concentration of iodide ion solution and amount of iodide ion exchanged. Mass of ion exchange resin $=1.000 \mathrm{~g}$, volume of labelled ionic solution $=250 \mathrm{ml}$, temperature $=35.0^{\circ} \mathrm{C}$. Correlation coefficient (r) for Duolite A-368 $=1.0000$. Correlation coefficient (r) for Duolite ARA-9366 $=1.0000$.

SIika 4 - Statistička korelacija između koncentracije jodidne otopine i množine izmijenjenih jodidnih iona. Masa ionskoizmjenjivačke smole $=1,000 \mathrm{~g}$, obujam obilježene ionske otopine $=250 \mathrm{ml}$, temperatura $=35,0{ }^{\circ} \mathrm{C}$. Korelacijski koeficijent (r) za Duolite A-368 $=1,0000$. Korelacijski koeficijent (r) za Duolite ARA-9366 $=1,0000$.

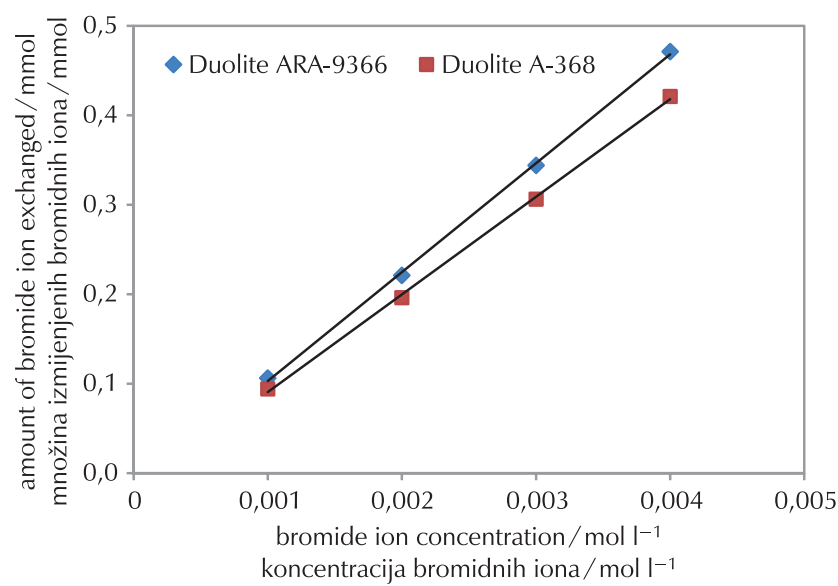

F i g . 5 - Statistical correlation between concentration of bromide ion solution and amount of bromide ion exchanged. Mass of ion exchange resin $=1.000 \mathrm{~g}$, volume of labelled ionic solution $=250 \mathrm{ml}$, temperature $=35.0^{\circ} \mathrm{C}$. Correlation coefficient $(\mathrm{r})$ for Duolite A-368 = 0.9996. Correlation coefficient (r) for Duolite ARA-9366 $=0.9998$.

S I i k a 5 - Statistička korelacija između koncentracije bromidne otopine i množine izmijenjenih bromidnih iona. Masa ionskoizmjenjivačke smole $=1,000 \mathrm{~g}$, obujam obilježene ionske otopine $=250 \mathrm{ml}$, temperatura $=35,0{ }^{\circ} \mathrm{C}$. Korelacijski koeficijent (r) za Duolite A-368 = 0,9996. Korelacijski koeficijent (r) za Duolite $A R A-9366=0,9998$.

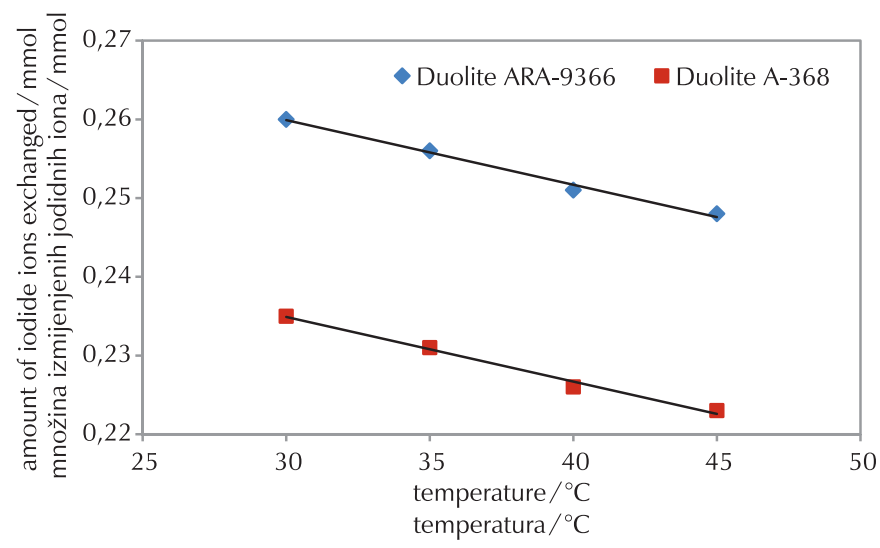

Fig . 6 - Statistical correlation between temperature of exchanging medium and amount of iodide ion exchanged. Mass of ion exchange resin $=1.000 \mathrm{~g}$, concentration of labelled exchangeable ion solution $=0.002 \mathrm{moll}^{-1}$, volume of labelled ionic solution $=250 \mathrm{ml}$, amount of exchangeable ions in $250 \mathrm{ml}$ of labelled solution $=0.500 \mathrm{mmol}$. Correlation coefficient $(\mathrm{r})$ for Duolite A-368 $=-0.9959$. Correlation coefficient (r) for Duolite ARA-9366 $=-0.9959$

S I i k a 6 - Statistička korelacija između temperature medija izmjene i množine izmijenjenih jodidnih iona. Masa ionskoizmjenjivačke smole $=1,000 \mathrm{~g}$, koncentracija obilježene otopine izmjenjivih iona $=0,002 \mathrm{moll}^{-1}$, obujam obilježene ionske otopine $=250 \mathrm{ml}$, množina izmjenjivih iona u $250 \mathrm{ml}$ obilježene otopine $=0,500$ mmol. Korelacijski koeficijent (r) za Duolite A-368 =-0,9959. Korelacijski koeficijent (r) za Duolite ARA-9366 $=-0,9959$. 


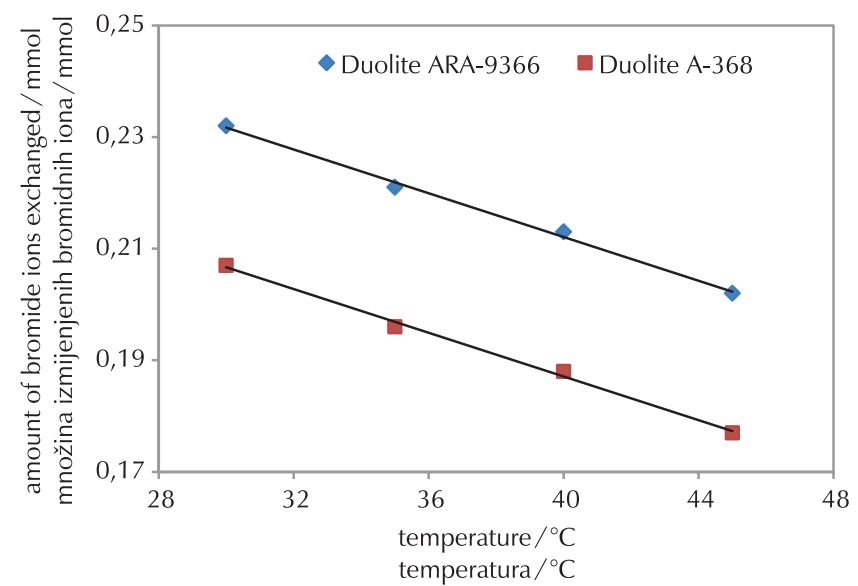

F i g . 7 - Statistical correlation between temperature of exchanging medium and amount of bromide ion exchanged. Amount of ion exchange resin $=1.000 \mathrm{~g}$, concentration of labelled exchangeable ion solution $=0.002 \mathrm{moll}^{-1}$, volume of labelled ionic solution $=250 \mathrm{ml}$, amount of exchangeable ions in $250 \mathrm{ml}$ labelled solution $=0.500 \mathrm{mmol}$. Correlation coefficient $(\mathrm{r})$ for Duolite A-368 $=-0.9981$. Correlation coefficient (r) for Duolite ARA-9366 $=-0.9981$.

S I i k a 7 - Statistička korelacija između temperature medija izmjene i množine izmijenjenih bromidnih iona. Masa ionskoizmjenjivačke smole $=1,000 \mathrm{~g}$, koncentracija obilježene otopine izmjenjivih iona $=0,002 \mathrm{moll}^{-1}$, obujam obilježene ionske otopine $=250 \mathrm{ml}$, množina izmjenjivih iona u $250 \mathrm{ml}$ obilježene otopine = 0,500 mmol. Korelacijski koeficijent (r) za Duolite A-368 = -0,9981. Korelacijski koeficijent (r) za Duolite ARA-9366 = -0,9981.

\section{Results and Discussion}

\section{Comparative study of ion-isotopic exchange reactions}

In the present investigation it was observed that because of the rapid ion-isotopic exchange reaction taking place, the radioactivity of solution decreases rapidly initially, then owing to the slow exchange, the radioactivity of the solution decreases slowly and finally remains nearly constant, thereby giving a composite curve (Fig. 1). The specific reaction rates $(k)$ of rapid ion-isotopic exchange reactions were calculated by resolving this composite curve. The amount of iodide/bromide ions exchanged on the resin were obtained from the initial and final radioactivity of solution and the amount of exchangeable ions in $250 \mathrm{ml}$ of solution. From the amount of ions exchanged on the resin and the specific reaction rates, the initial rate of ion exchanged was calculated. ${ }^{20-25}$

Because of larger solvated size of bromide ions as compared with that of iodide ions, it was observed that the exchange of bromide ions occurred at a slower rate than that of iodide ions. Hence, under identical experimental conditions, the values of specific reaction rates, amount of ion exchanged and initial rate of ion exchange were calculated to be lower for bromide ion-isotopic exchange reaction than that for iodide ion-isotopic exchange reaction as summarized in Tables 1 and 2. For both bromide and iodide ion-isotopic exchange reactions, under identical experimental conditions, the values of specific reaction rate increased with the increase in concentration of ionic solution from 0.001 to $0.004 \mathrm{~mol} \mathrm{I}^{-1}$ (Table 1). However, with rise in temperature from $30.0^{\circ} \mathrm{C}$ to $45.0{ }^{\circ} \mathrm{C}$, the specific reaction rate was observed to decrease (Table 2). Thus, in case of Duolite ARA-9366 at $35.0{ }^{\circ} \mathrm{C}$ when the ionic concentration increased from 0.001 to $0.004 \mathrm{~mol} \mathrm{I}^{-1}$, the specific reaction rate values for iodide ion-isotopic exchange increased from 0.164 to $0.200 \mathrm{~min}^{-1}$, and for bromide ion-isotopic exchange the values increased from 0.135 to $0.151 \mathrm{~min}^{-1}$. Similarly, in the case of Duolite A-368, under identical experimental conditions, the values for iodide ion-isotopic exchange increased from 0.112 to $0.153 \mathrm{~min}^{-1}$, and for bromide ion-isotopic exchange the values increased from 0.097 to $0.126 \mathrm{~min}^{-1}$. The observed increase in values of specific reaction rate with the increase in ionic concentration was attributable to the decrease in swelling pressure of the resins. Similar results were reported previously for iodide ion-isotopic exchange reactions using Tulsion A-23 and Indion-810 resins in that the specific reaction rate values increased from 0.208 to $0.233 \mathrm{~min}^{-1}$ and from 0.090 to $0.133 \mathrm{~min}^{-1}$ respectively under identical experimental conditions. ${ }^{26}$ Nevertheless, when concentration of ionic solution was kept constant at $0.002 \mathrm{~mol} \mathrm{I}^{-1}$ and temperature was raised from $30.0{ }^{\circ} \mathrm{C}$ to $45.0{ }^{\circ} \mathrm{C}$, in the case of Duolite ARA-9366 the specific reaction rate values for iodide ion-isotopic exchange decreased from 0.185 to $0.155 \mathrm{~min}^{-1}$, and for bromide ion-isotopic exchange the values decreased from 0.147 to $0.127 \mathrm{~min}^{-1}$. Similarly, in case of Duolite A-368, under identical experimental conditions, the specific reaction rate values for iodide ion-isotopic exchange decreased from 0.140 to $0.109 \mathrm{~min}^{-1}$, and for bromide ion-isotopic exchange the values decreased from 0.113 to $0.091 \mathrm{~min}^{-1}$. Here it is presumed that owing to the rise in temperature, the swelling pressure of the resins increases thus resulting in decreased values of specific reaction rate. The results obtained here were similar to those reported previously for iodide ion-isotopic exchange reactions using Tulsion A-23 and Indion-810 resins in that the specific reaction rate values decreased from 0.222 to $0.206 \mathrm{~min}^{-1}$ and from 0.121 to $0.084 \mathrm{~min}^{-1}$ respectively under identical experimental conditions. ${ }^{26}$ From the results, it appears that iodide ions exchange at a faster rate as compared to that of bromide ions which was related to the extent of solvation (Tables 1 and 2).

From the knowledge of $A_{\mathrm{i}}, A_{\mathrm{f}}$, the volume of exchangeable ionic solution $(V)$ and mass of ion exchange resin $(m)$, the $K_{d}$ value was calculated by the equation

$$
K_{\mathrm{d}}=\left[\left(A_{\mathrm{i}}-A_{\mathrm{f}}\right) / A_{\mathrm{f}}\right] \cdot V / m
$$

Previous studies ${ }^{27,28}$ on halide ion distribution coefficient on strong and weak basic anion exchange resins indicated that the selectivity coefficient between halide ions increased at higher electrolyte concentrations. Adachi et al. ${ }^{29}$ observed that the swelling pressure of the resin decreased at higher solute concentrations resulting in larger $K_{d}$ values. The temperature dependence of $K_{d}$ values on cation exchange resin was studied by Shuji et al. ${ }^{30}$ where they observed that the values of $K_{d}$ increased with fall in temperature. The present experimental results also indicate that the $K_{d}$ values for bromide and iodide ions increase with increase in ionic concentration of the external solution; nevertheless, with the rise in temperature the $K_{d}$ values were found to decrease. Thus, in the case of Duolite ARA-9366 at $35.0{ }^{\circ} \mathrm{C}$ when the ionic 
concentration increased from $0.001 \mathrm{moll}^{-1}$ to $0.004 \mathrm{moll}^{-1}$, the $\log \left(K_{\mathrm{d}} / \mathrm{ml} \mathrm{g}^{-1}\right)$ values for iodide ions increased from 7.4 to 8.9 , and for bromide ions the values increased from 3.6 to 5.6. Similarly, in the case of Duolite A-368, under identical experimental conditions, the $\log \left(K_{\mathrm{d}} / \mathrm{ml} \mathrm{g}^{-1}\right)$ values for iodide ions increased from 6.4 to 8.0, and for bromide ions the values increased from 2.7 to 4.5. Similar results were obtained previously in which the $\log \left(K_{\mathrm{d}} / \mathrm{ml} \mathrm{g}^{-1}\right)$ values for bromide ions were reported to have increased from 2.90 to 3.94 and from 4.28 to 5.48, respectively for Duolite A-161 and Duolite A-162 resins when the concentration of bromide ions was increased from 0.005 to $0.100 \mathrm{moll}^{-1}$ at a constant temperature of $25.0{ }^{\circ} \mathrm{C} .{ }^{31}$ Nevertheless, when the concentration of ionic solution was kept constant at $0.002 \mathrm{~mol} \mathrm{I}^{-1}$ and temperature was raised from $30.0{ }^{\circ} \mathrm{C}$ to $45.0^{\circ} \mathrm{C}$, in the case of Duolite ARA-9366, the $\log \left(K_{d} / \mathrm{ml} \mathrm{g}^{-1}\right)$ values for iodide ions decreased from 8.4 to 6.8 , and for bromide ions the values decreased from 5.2 to 3.5. Similarly, in the case of Duolite A-368, under identical experimental conditions, the $\log \left(K_{\mathrm{d}} / \mathrm{ml} \mathrm{g}^{-1}\right)$ values for iodide ions decreased from 7.6 to 5.8 , and for bromide ions the values decreased from 4.4 to 2.8 . Similar results were obtained previously in which the $\log \left(K_{\mathrm{d}} / \mathrm{ml} \mathrm{g}^{-1}\right)$ values for bromide ions were reported to have decreased from 2.90 to 2.34 and from 4.28 to 3.60 for Duolite A-161 and Duolite A-162 resins, respectively, when the temperature was raised from $25.0{ }^{\circ} \mathrm{C}$ to $45.0{ }^{\circ} \mathrm{C}$ using $0.005 \mathrm{~mol} \mathrm{I}^{-1}$ bromide ion solution. ${ }^{31}$ It was also observed that the $K_{d}$ values for iodide ion-isotopic exchange reaction were calculated to be higher than those for bromide ion-isotopic exchange reaction (Tables 1 and 2).

\section{Comparative study of anion exchange resins}

From Tables 1 and 2, it was observed that for iodide ion-isotopic exchange reaction by using Duolite ARA-9366 resin, the values of specific reaction rate, amount of iodide ion exchanged, initial rate of iodide ion exchange and $\log \left(K_{\mathrm{d}} / \mathrm{ml} \mathrm{g}^{-1}\right)$ were $0.173,0.256,0.044$ and 7.9 respectively, which was higher than $0.129,0.231,0.030$ and 6.9 respectively as obtained by using Duolite A-368 resins under identical experimental conditions of $35.0^{\circ} \mathrm{C}, 1.000 \mathrm{~g}$ of ion exchange resins and $0.002 \mathrm{~mol} \mathrm{I}^{-1}$ labelled iodide ion solution. The identical trend was observed for the two resins during bromide ion-isotopic exchange reaction.

From Table 1, it was observed that using Duolite ARA-9366 resins, at a constant temperature of $35.0^{\circ} \mathrm{C}$, as the concentration of labelled iodide ion solution increases from 0.001 to $0.004 \mathrm{moll}^{-1}$, the fraction of iodide ions exchanged increases from $50.0 \%$ to $52.5 \%$. When using Duolite A-368 resins under identical experimental conditions, the fraction of iodide ions exchanged increases from $45.0 \%$ to $47.5 \%$. Similarly in the case of bromide ion-isotopic exchange reaction, the fraction of bromide ions exchanged increases from $42.4 \%$ to $47.1 \%$ using Duolite ARA-9366 resin, but for Duolite A-368 resin it increases from $37.4 \%$ to $42.1 \%$. The results obtained here agree well with those reported previously for iodide ion-isotopic exchange reactions using Tulsion A-23 and Indion-810 resins in which the fraction of iodide ions exchanged increased from $55.49 \%$ to $61.44 \%$ and from $29.40 \%$ to $42.25 \%$, respectively, under identical experimental conditions. ${ }^{26}$ The increase in fraction of ions exchanged observed here may be due to the decrease in swelling pressure of the resin with the rise in ionic concen- tration. The effect of ionic concentration on fraction of ions exchanged is graphically represented in Fig. 2.

From Table 2, it was observed that using Duolite ARA-9366 resins, for $0.002 \mathrm{~mol} \mathrm{I}^{-1}$ labelled iodide ion solution, as the temperature increased from $30.0^{\circ} \mathrm{C}$ to $45.0^{\circ} \mathrm{C}$, the fraction of iodide ions exchanged decreased from $52.0 \%$ to $49.5 \%$. While using Duolite A-368 resins under identical experimental conditions, the fraction of iodide ions exchanged decreased from $47.0 \%$ to $44.5 \%$. Similarly, in the case of bromide ion-isotopic exchange reaction, the fraction of bromide ions exchanged decreased from $46.4 \%$ to $40.3 \%$ using Duolite ARA-9366 resin, and for Duolite A-368 resin it decreased from $41.4 \%$ to $35.3 \%$. Here it is presumed that due to the rise in temperature, the swelling pressure increased thus resulting in a decreased fraction of ions exchanged. The results obtained here are similar to those reported previously for iodide ion-isotopic exchange reactions using Tulsion A-23 and Indion-810 resins in which the fraction of iodide ions exchanged decreased from $59.75 \%$ to $54.87 \%$ and from $38.70 \%$ to $27.60 \%$ under identical experimental conditions. ${ }^{26}$ The effect of temperature on the fraction of ions exchanged is graphically represented in Fig. 3.

It appears that higher moisture content of $55 \%$ in Duolite ARA-9366 resins has resulted in greater swelling and larger pore size as compared with that of Duolite A-368 resins having less moisture content of $46 \%$. Therefore, under identical experimental conditions, compared to Duolite A-368, the Duolite ARA-9366 resin shows higher fraction of ions exchanged indicating its superior performance.

\section{Statistical Correlations}

The results of this investigation show a strong positive linear co-relationship between the amount of ions exchanged and the concentration of ionic solution (Figs. 4, 5). In the case of iodide ion-isotopic exchange reaction, the value of correlation coefficient $(r)$ was calculated as 1.0000 for both the resins, and for bromide ion-isotopic exchange reaction, the values of $r$ was calculated as 0.9998 and 0.9996 for Duolite ARA-9366 and Duolite A-368 resins, respectively.

There also exists a strong negative co-relationship between the amount of ions exchanged and the temperature of exchanging medium (Figs. 6, 7). In the case of iodide ion-isotopic exchange reactions, the value of $r$ was calculated as -0.9959 for both the resins. Similarly, in the case of bromide ion-isotopic exchange reactions, the $r$ value was calculated as -0.9981 for both the resins.

\section{Conclusion}

The increasing importance of organic ion exchangers in nuclear power plant operations and the fuel reprocessing sector for the treatment of liquid radioactive waste is recognized globally. In spite of extensive work done on the development of new organic ion exchange resins to match the requirements in industries, different aspects of ion exchange technologies are still studied continuously to improve the performance of those resins in various technical applications. Such types of studies are essential in characterization of ion exchange resins. Although there are many alternative methods available for characterization of ion exchange resins, the radioisotopic tracer technique has emerged as a sensitive, non-destructive analytical technique. 
Considering the extensive industrial application of tracer isotopes, in this paper has been successfully demonstrated their application in performance evaluation of two industrial grade anion exchange resins. It is assumed that the results obtained from such studies shall help standardize the operational process parameters to improve the performance of ion exchange resins in various industrial processes. The radioactive tracer technique used here may also be extended further for characterization of different nuclear as well as non-nuclear grade ion exchange resins.

\section{ACKNOWLEDGEMENT}

The author thanks Professor Dr. R. S. Lokhande (retired) for his valuable help and support by providing the required facilities to carry out the experimental work in the Radiochemistry Laboratory, Department of Chemistry, University of Mumbai, Vidyanagari, Mumbai 58.

\section{List of symbols \\ Popis simbola}

\begin{tabular}{|c|c|}
\hline$A$ & $\begin{array}{l}\text { - radioactivity } \\
\text { - radioaktivnost }\end{array}$ \\
\hline$A_{\mathrm{f}}$ & $\begin{array}{l}\text { - final radioactivity } \\
\text { - konačna radioaktivnost }\end{array}$ \\
\hline$A_{\mathrm{i}}$ & $\begin{array}{l}\text { - initial radioactivity } \\
\text { - početna radioaktivnost }\end{array}$ \\
\hline$K_{\mathrm{d}}$ & $\begin{array}{l}\text { - ion-isotopic exchange reaction constant, } \mathrm{ml} \mathrm{g}^{-1} \\
\text { - reakcijska konstanta ionske izmjene, } \mathrm{ml} \mathrm{g}^{-1}\end{array}$ \\
\hline$k$ & $\begin{array}{l}\text { - specific reaction rate, } \min ^{-1} \\
\text { - specifična brzina reakcije, } \min ^{-1}\end{array}$ \\
\hline$r$ & $\begin{array}{l}\text { - correlation coefficient } \\
\text { - korelacijski koeficijent }\end{array}$ \\
\hline$m$ & $\begin{array}{l}\text { - mass, g } \\
\text { - masa, g }\end{array}$ \\
\hline$V$ & $\begin{array}{l}\text { - volume, } \mathrm{ml} \\
\text { - obujam, ml }\end{array}$ \\
\hline
\end{tabular}

\section{References \\ Literatura}

1. S. K. Samanta, M. Ramaswamy, B. M. Misra, Studies on cesium uptake by phenolic resins, Sep.Sci. Technol. 27 (1992) 255-267, doi: http://dx.doi.org/10.1080/01496399208018877.

2. S. K. Samanta, M. Ramaswamy, P. Sen, N. Varadarajan, R. K. Singh, Removal of radiocesium from alkaline IL waste, Natl Symp. On Management of Radioactive and Toxic Wastes (SMART-93), Kalpakkam, 1993, Bhabha Atomic Research Centre, Bombay, 1993, pp. 56-58.

3. S. K. Samanta, T. K. Theyyunni, B. M. Misra, Column behavior of a resorcinol-formaldehyde polycondensate resin for radiocesium removal from simulated solution, J. Nucl. Sci. Technol. 32 (1995) 425-429, doi: http://dx.doi.org/10.1080 /18811248.1995.9731727.

4. Y. Kulkarni, S. K. Samanta, S. Y. Bakre, K. Raj, M. S. Kumra, Process for treatment of intermediate level radioactive waste based on radionuclide separation, Waste Management '96 (Proc. Int. Symp Tucson, AZ, 1996), Arizona Board of Regents, Phoenix, AZ, 1996 (CD-ROM).

5. L. A. Bray, R. J. Elovich, K. J. Carson, Cesium Recovery using Savannah River Laboratory Resorcinol-formaldehyde Ion Exchange Resin, Rep. PNL-7273, Pacific Northwest Lab., Richland, WA (1990).
6. M. Tomoi, K. Yamaguchi, R. Ando, Y. Kantake, Y. Aosaki, H. Kubota, Synthesis and thermal stability of novel anion exchange resins with spacer chains, J. Appl. Poly. Sci. 64 (6) (1997) 1161-1167, doi: http://dx.doi.org/10.1002/(SICI)10974628(19970509)64:6<1161::AID-APP16>3.3.CO;2-L.

7. L. Zhu, Y. Liu, J. Chen, Synthesis of N-Methylimidazolium Functionalized Strongly Basic Anion Exchange Resins for Adsorption of Cr (VI), Ind. Eng. Chem. Res. 48 (7) (2009) 3261-3267, doi: http://dx.doi.org/10.1021/ie801278f.

8. V. V. Korshak, S. V. Rogozhin, V. A. Davankov, S. G. Vyrbanov, Synthesis of optically active ion exchange resins, Russ. Chem. B. 15 (3) (1966) 510-512, doi: http://dx.doi. org/10.1007/BF00846116.

9. P. U. Singare, R. S. Lokhande, R. S. Madyal, Thermal Degradation Studies of Some Strongly Acidic Cation Exchange Resins, Open Journal of Physical Chemistry 1 (2) (2011) 45-54, doi: http://dx.doi.org/10.4236/ojpc.2011.12007.

10. P. U. Singare, R. S. Lokhande, R. S. Madyal, Thermal Degradation Studies of Polystyrene Sulfonic and Polyacrylic Carboxylic Cationites, Rus. J. Gen. Chem. 80 (3) (2010) 527-532, doi: http://dx.doi.org/10.1134/S1070363210030266.

11. R. Kumaresan, K. N. Sabharwal, T. G. Srinivasan, P. R. Vasudeva Rao, G. Dhekane, Evaluation of New Anion Exchange Resins for Plutonium Processing, Solvent Extr. Ion Exc. 24 (4) (2006) 589602, doi: http://dx.doi.org/10.1080/07366290600762512.

12. J. L. Cortina, A. Warshawsky, N. Kahana, V. Kampel, C. H. Sampaio, R. M. Kautzman, Kinetics of goldcyanide extraction using ion-exchange resins containing piperazine functionality, React. Funct. Polym. 54 (1-3) (2003) 25-35, doi: http://dx.doi. org/10.1016/S1381-5148(02)00180-3.

13. W. B. Gurnule, S. S. Dhote, Preparation, Characterization and Chelating lon-exchange Properties of Copolymer Resin Derived from 2,4-Dihydroxy Benzoic Acid, Ethylene Diamine and Formaldehyde, Der Pharma Chemica 4 (2) (2012) 791-799.

14. T. Sata, Ion Exchange Membranes: Preparation, Characterization, Modification, and Applications, Royal Society of Chemistry, Cambridge CB4 OWF, UK, 2004, pp. 90-117.

15. W. B. Gurnule, C. S. Makde, M. Ahmed, Synthesis, Characterization, Morphology, Thermal, Electrical and Chelation Ion Exchange Properties of a Copolymer Resin, J. Environ. Res. Develop. 7(3) (2013) 1183-1192.

16. E. Muller, C. Mann, Resin characterization by electro-acoustic measurements, J. Chromatogr. A 1144 (1) (2007) 30-39, doi: http://dx.doi.org/10.1016/j.chroma.2006.11.103.

17. B. C. Dixit, R. B. Dixit, D. J. Desai, Synthesis and characterization of novel ion-exchange resin based on polyimide containing 8-hydroxyquinoline as a pendent groups, J. Polym. Res. 17 (4) (2010) 481-488, doi: http://dx.doi.org/10.1007/s10965009-9334-3.

18. Radiotracer Applications in Industry - A Guidebook, Safety Reports Series No. 423, International Atomic Energy Agency, Vienna, 2004.

19. D. D. Sood, Advances in industrial applications of radioisotopes, in D. D. Sood, A. V. R. Reddy, S. R. K. Iyer, S. Gangadharan, G. Singh (ed.), Proc. Int. Conf. on Applications of Radioisotopes and Radiation in Industrial Development, B.A.R.C., India, 1998, pp. 35-53.

20. R. S. Lokhande, P. U. Singare, A. B. Patil, Application of Radioactive Tracer Technique on Industrial Grade Ion Exchange Resins Indion-830 (Type-1) and Indion-N-IP (Type-2), Radiochim. Acta 95 (1) (2007) 111-114, doi: http://dx.doi.org/10.1134/ S1066362208060106.

21. R. S. Lokhande, P. U. Singare, V. V. Patil, Application of Radioactive Tracer Technique to Study the Kinetics and Mechanism of Reversible Ion-Isotopic Exchange Reaction using Strongly Basic Anion Exchange Resin Indion-850, Radiochemistry 50 (6) (2008) 638-641. 
22. R. S. Lokhande, P. U. Singare, T. S. Prabhavalkar, The Application of the Radioactive Tracer Technique to Study the Kinetics of Bromide Isotope Exchange Reaction with the Participation of Strongly Basic Anion Exchange Resin Indion FF-IP, Russ. J. Physical Chemistry A 82 (9) (2008) 1589-1595, doi: http:// dx.doi.org/10.1134/S0036024408090331.

23. R. S. Lokhande, P. U. Singare, S. R. D. Tiwari, Kinetics of bromide ion-isotope exchange with weakly basic macroporous resin Indion-860, Radiochemistry 50 (6) (2008) 633-637, doi: http://dx.doi.org/10.1134/S106636220806009X.

24. P. U. Singare, R. S. Lokhande, Studies on Ion-Isotopic Exchange Reactions Using Nuclear Grade Ion Exchange Resins, lonics 18 (4) (2012) 351-357, doi: http://dx.doi.org/10.1007/s11581011-0645-0.

25. R. S. Lokhande, P. U. Singare, Comparative Study on lodide and Bromide Ion-Isotopic Exchange Reactions by Application of Radioactive Tracer Technique, J. Porous Mater. 15 (3) (2008) 253-258, doi: http://dx.doi.org/10.1007/s10934-006-9077-z.

26. P. U. Singare, Comparative Study of Tulsion A-23 and Indion-810 Strongly Basic Anion Exchange Resins By Application of ${ }^{131} \mathrm{I}$ as a Tracer Isotope, Physical Chemistry 2 (3) (2012) 3742, doi: http://dx.doi.org/10.5923/j.pc.20120203.03.

27. K. G. Heumann, K. Baier, Chloride distribution coefficient on strongly basic anion-exchange resin: Dependence on co-ion in alkali fluoride solutions, Chromatographia 15 (11) (1982) 701-703, doi: http://dx.doi.org/10.1007/BF02261888.

28. P. U. Singare, R. S. Lokhande, V. V. Patil, T. S. Prabhavalkar, S. $R$. D. Tiwari, Study on Distribution coefficient of Bromide ions from Aqueous Solution on Ion Exchange Resins Indion-850, Indion-860 and Indion FF-IP, European J. Chemistry 1 (1) (2010) 47-49, doi: http://dx.doi.org/10.5155/eurjchem.1.1.47-49.7.

29. S. Adachi, T. Mizuno, R. Matsuno, Concentration dependence of the distribution Coefficient of maltooligosaccharides on a cation-exchange resin, J. Chromatogr. A 708 (1995) 177-183, doi: http://dx.doi.org/10.1016/0021-9673(95)00405-C.

30. A. Shuji, M. Takcshi, M. Ryuichi, Temperature Dependence of the Distribution Coefficient of Maltooligosaccharides on Cation-exchange Resin in $\mathrm{Na}^{+}$Form, Biosci. Biotechnol. Biochem. 60 (2) (1996) 338-340, doi: http://dx.doi.org/10.1271/ bbb.60.338.

31. P. U. Singare, R. S. Lokhande, P. Karthekayan, S. R. D. Tiwari, Study on Distribution Coefficient of Bromine lons from Aqueous Solution on Ion Exchange Resins Duolite A-161 and Duolite A-162, Colloid Journal 72 (6) (2010) 874-876, doi: http:// dx.doi.org/10.1134/S1061933X10060207.

\title{
SAŽETAK \\ Vrednovanje industrijskih smola Duolite ARA-9366 i Duolite A-368 na osnovi učinka
}

\author{
P. U. Singare
}

Istraživane su smole nuklearne i nenuklearne kvalitete Duolit ARA-9366 i Duolit A-368 radioanalitičkim metodama. Vrednovanje je temeljeno na kinetici ionske izmjene radioaktivnih obilježivača ${ }^{151} \mathrm{I} \mathrm{i}{ }^{82} \mathrm{Br}$. Pod istim eksperimentalnim uvjetima $\left(35,0{ }^{\circ} \mathrm{C}\right.$; 1,000 g ionskoizmjenjivačke smole; koncentracija jodida $0,002 \mathrm{~mol} \mathrm{I}^{-1}$ u obilježenoj otopini) specifične brzine reakcije i početne brzine ionske izmjene bile su 0,173 $\mathrm{min}^{-1}$ i $0,044 \mathrm{mmol} \mathrm{min}^{-1}$ za Duolite ARA-9366, što je više nego $0,129 \mathrm{~min}^{-1}$ i $0,030 \mathrm{mmol} \mathrm{min}^{-1}$ za Duolite A-368. Jednaka tendencija uočena je u izotopnoj izmjeni bromidnog iona.

Za obje smole utvrđena je jaka korelacija između množine izmijenjenih iona i koncentracije iona, te jaka negativna korelacija između množine izmijenjenih iona i temperature. Rezultati istraživanja pokazuju veću učinkovitost smole Duolite ARA-9366 od Duolite A-368 pri jednakim eksperimentalnim uvjetima.

Department of Chemistry, Bhavan's College

Prispjelo 27. travnja 2013. Munshi Nagar, Andheri (West) Prihvaćeno 26. kolovoza 2013. 400058 Mumbai Indija 